\title{
REAKTÍV PLAZMAPORLASZTÁSI FOLYAMAT AUTOMATIZÁLÁSA
}

\section{AUTOMATION OF THE REACTIVE MAGNETRON SPUTTERING PROCESS}

\author{
Fekete Albert-Zsombor ${ }^{1,2}$ \\ ${ }^{1}$ S.C. Tetronic S.R.L., 547530, Románia, Marosszentgyörgy, Wesselényi Erzsébet ut- \\ ca 6 szám; Tel.+40-766-649950, zsombor.fekete@tetronic.ro \\ ${ }^{2}$ Sapientia - Erdélyi Magyar Tudományegyetem, Marosvásárhelyi Kar, 540485, \\ Románia, Marosvásárhely, Segesvári út 1C; Tel. +40-766-649950; levelezési cím: \\ zsombor.fekete@tetronic.ro
}

\begin{abstract}
The reactive magnetron plasma sputtering process used to create various thin film coatings is a highly unstable process, which requires control. The aim of the paper is to present the structure of a particular multilayer hierarchical control system, which contributes to the measurement, processing, data archiving and the control of various interdependent parameters of the sputtering process. The paper presents in detail the digital communication protocol and proposes a mechanism for synchronization of different units of the distributed system.
\end{abstract}

Keywords: reactive magnetron sputtering, embedded systems, network, communication protocol, embedded SNTP client

\section{Összefoglalás}

A különféle vékonyréteg-bevonatok elöállítására alkalmazott reaktív magnetronos plazmaporlasztási eljárás rendkívül instabil folyamat, amely szükségessé teszi a szabályozást. A dolgozat célja egy sajátos többszintü hierarchikus irányítási rendszer felépítésének ismertetése, amely nagymértékben hozzájárul a porlasztási folyamat valamennyi paraméterének a méréséhez, feldolgozásához, tárolásához és szabályozásához. A dolgozat hangsúlyosan tárgyalja a digitális kommunikációs protokollt és az osztott rendszer elemeinek szinkronizálására javasolt eljárást.

Kulcsszavak: reaktív plazmaporlasztási folyamat, beágyazott rendszerek, hálózat, kommunikációs protokoll, beágyazott SNTP kliens

\section{Bevezető}

A Sapientia Erdélyi Magyar Tudományegyetem marosvásárhelyi karán létrehozott és müködtetett Vékonyréteg Fizika kutatólaboratórium munkatársai többnyire kopásálló nanoszerkezetű vékonyréteg-bevonatok elöállítására és szerkezeti összetételének elemzésére irányuló kutatásokat végeznek. Jelen kutatás során a kitüzött cél egy irányí- tási hálózat kiépítése, melynek köszönhetöen lehetőség nyílik az egyenáramú magnetronos plazmaporlasztási folyamat komplex vezérlési és szabályozási feladatainak leosztására folyamatközeli beágyazott rendszerekre, több szinten történő adatmentés megvalósítására, biztonsági szolgáltatások beágyazására [3], valamint a mért és számolt értékek irányítási rétegben történő 
központosított elérésére folyamatirányító számítógépes alkalmazás (SCADA) révén.

Ugyanakkor fontos kiemelnünk, hogy a vákuumrendszer szennyeződésének elkerülése végett bevezetett folyamatos vákuumozás fenntartása feltételezi a bemutatott rendszerek közel 70\%-ának szünetmentes üzemelését, így a beágyazott rendszerek megfelelő hűtésének biztosítása mellett a redundanciákra épülő védelmi rendszer [3] bevezetése is kulcsfontosságú.

\section{Kísérleti berendezés}

A porlasztóberendezés felépítésében részt vevő és a hierarchikus rendszer kialakítása során használt elemek közül a legfontosabbak: a gázelegy összetételének meghatározására használt kvadrupól típusú tömegspektrométer (Leybold-Heraeus QM210 és PGA100), kapacitív (Pfeiffer Vacuum CMR365), Pennig és Piráni (Pfeiffer Vacuum MPT100) típusú nyomásmérők, a lepkeszelep beavatkozó (Futaba
S3152 szervóhajtás és Hengsler RI41 enkóder), a hőmérséklet- (DS18S20), hütővízhozam- és páratartalom-érzékelők (SHT11), a három gázhozamszabályozó (SEC 400), a vákuumrendszer felépítésében részt vevő különféle elővákuum és turbomolekuláris szivattyúk (Osaka Vacuum H5000F), és a felsőbb szinteken lévő beágyazott saját fejlesztésủ vezérlőegységek, mint például a dinamikus nyomásszabályozó (PCU), a tömegspektrométer vezérlő (QMS), valamint a hütési és védelmi feladatokat ellátó beágyazott rendszer (CSC) [3].

A kiépített osztott rendszer elemei, ahogyan az 1. ábrán is megfigyelhetjük, egy többszintü hierarchikus rendszerbe szerveződnek:

- felhasználói szint;

- irányítási szint;

- érzékelők és beavatkozók szintje.

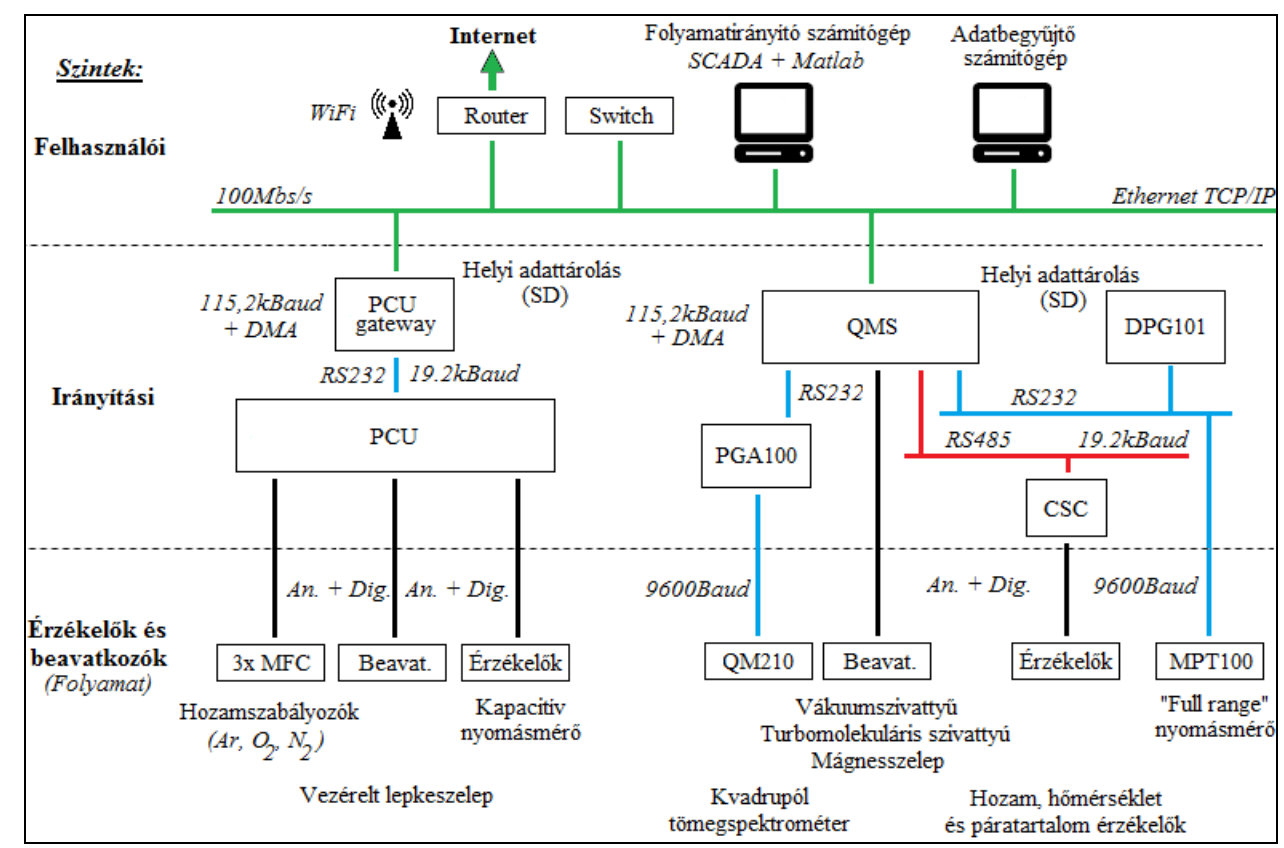

1. ábra. A reaktív plazmaporlasztási folyamat szabályozására kialakitott többszintes hierarchikus irányitási rendszer felépitését szemléltetö tömbvázlat 
Minden réteg jól meghatározott és elkülöníthető feladatot lát el. Ennek fényében kiemelhetjük, hogy a folyamatközeli rétegek szintjén vannak megoldva a mérési, beavatkozási és irányítási feladatok, valamint a lokális microSD adathordozóra, rendszerint a szabályozó mintavételi frekvenciájával történő adatmentés. Felfele haladva, bár nő az adatátviteli sebesség és a cserélt adatmennyiség, a válaszidő pontos meghatározásának lehetősége csökken. Ennek magyarázata a 2.2 alfejezetben olvasható.

\subsection{Kommunikációs protokoll}

A megvalósított osztott rendszer esetében szükségessé vált egy egységes kommunikációs protokoll és csomagszerkezet kidolgozása, amely használható szinkron és aszinkron soros kommunikáció, valamint Ethernet hálózaton küldött TCP csomagok esetében egyaránt, hardver platformtól és adatmérettől (6B..4kB) függetlenül.

A javasolt megoldás egy többrétegü függvénycsalád, amelynek felépítését a 2. ábrán láthatjuk. A kialakított függvények három, jól elhatárolható rétegbe szerveződnek:

- alkalmazási vagy felhasználói réteg;

- csomagfeldolgozó és ütemező réteg; - platformspecifikus réteg.

Az algoritmus adaptalása különböző számítástechnikai eszközökre csupán a legalsó rétegben lévő hardverspecifikus utasítások és függvények lecserélését feltételezi. Amennyiben a beágyazott rendszer (rendszerint fejlettebb architektúrával rendelkező mikrovezérlővel ellátott elektronikai áramkör) tartalmaz Direct Memory Access (DMA) meghajtót, akkor az algoritmus automatikusan függetleníti a processzortól a kommunikációs periféria és a belső RAM memória közötti adatcserét. Ennek eredményeképpen a kialakított protokoll beágyazható 8,16 vagy 32 bittes architektúrával rendelkező mikrovezérlőkbe, valamint alkalmazható a folyamatirányító számítógé-

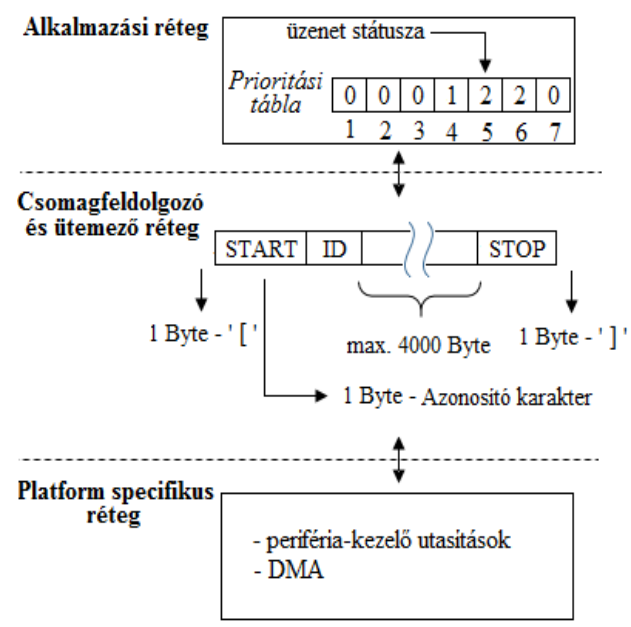

2. ábra. Kommunikációs protokoll - platform független többrétegü függvénycsalád felépitése

pen futtatott SCADA és Matlab alkalmazások esetében is.

Haladva felfele a következő réteg felelős a kimenő üzenetek összeállításáért, valamint a bejövők feldolgozásáért és az így kapott adatok RAM-ban lévő adatstruktúrákba történő tárolásáért. Voltaképp ezen a szinten definiáljuk a változó méretü csomagszerkezeteket. A típusazonosító (2. ábra - ID) alapján nemcsak az üzenet mérete és feldolgozási módja határozható meg, hanem a céleszköz is. Ezáltal az osztott rendszer bármely pontjába küldhetö adatcsomag, függetlenül az adatátviteli közegtől és a köztes csomópontok számától. A felhasználói rétegben belső időzítők és a prioritási tábla segítségével kiválasztható az adott sorszámú csomag küldési módja: 0 nem küldjük el, 1 - csak egyszer küldjük el, 2 - minden üzenetküldési ciklusban elküldjük. A kialakított struktúrának köszönhetően egy időben több üzemmód is megvalósítható:

- ciclikus küldés testre szabható küldési frekvenciával, többnyire a mért értékek (32B..4kB) és a védelmi rendszer állapotjelzői számára fenntartott üzemmód ( 6B); 
- aciklikus küldés állapotok számára, azaz csak változás esetén kerül elküldésre a kívánt állapot;

- kérésre történő egyszeri küldés, mint például a tömegspektrométer konfigurációs állományának $(\sim 1 \mathrm{kB})$ vagy a referenciaértékeknek (5B..0,5kB) a küldése.

A küldési frekvenciát egyértelmüen a mért paraméter változási sebessége és a mintavételi periódus határozza meg, amely $40 \mathrm{~ms}$ és 2-3 s között változhat. Ezen üzemmódok együttes alkalmazásának segítségével az adatforgalom optimalizálását kívántuk elérni, elkerülve a fölösleges adatforgalmat.

\subsection{Szinkronizálás - SNTP kliens}

Osztott rendszerek esetében használt kommunikációs hálózatoknál felmerülnek időzítési és szinkronizációs problémák. Megfigyelhetjük, hogy a folyamatközeli szinteken használt aszinkron RS232, valamint a mester-szolga kialakításban működtetett RS485 lokális hálózatok esetében nem jelennek meg ütközések, hiszen egy időben csak egy egység használja az adatátviteli közeget, és ennek eredményeképpen nem beszélhetünk vonalhozzáférési hibák megjelenéséről. Ismerve a helyi hálózatok adatátviteli sebességét, az üzenetek küldési frekvenciáját, a csomagok méretét, valamint az optikai leválasztók által behozott $\mathrm{B} / \mathrm{ns}$ nagyságrendủ késéseket könnyedén meghatározható az üzenetek érkezési frekvenciája, amely időben állandó. Ennek eredményeképpen az irányítási rétegben kerültek implementálásra a gyors szabályozóhurkok, mint például a három gázhozamszabályozó [1], valamint az adaptív PID és Fuzzy szabályozási struktúrákkal megvalósított dinamikus nyomásszabályozás [1]. Az elmondottak a felhasználói szinten lévő Ethernet hálózatra nem érvényesek, hiszen a TCP csomagok formájában küldött adatok esetében biztosítani tudjuk az üzenetek megérkezését, azonban változó a küldés és fogadás között eltelt idő. Ez a jelenség többnyire az adatátviteli közegben fellépő ütközéseknek tulajdonítható, más szóval függ a hálózat terhelési fokától.

Annak érdekében, hogy a SCADA alkalmazás időrendi sorrendbe tudja rendezni a két vezérlőegységtől kapott csomagokat, minden üzenet felhasználói része tartalmaz egy sajátos időbélyeget. Ezen eljárás csak akkor müködik, ha a két beágyazott rendszer belső számlálói szinkronizálva vannak. Erre a feladatra egy SNTP (,, Simple Network Time Protocol") kliens alkalmazás beágyazását [2] valósítottuk meg a mikrovezérlős rendszerekbe.

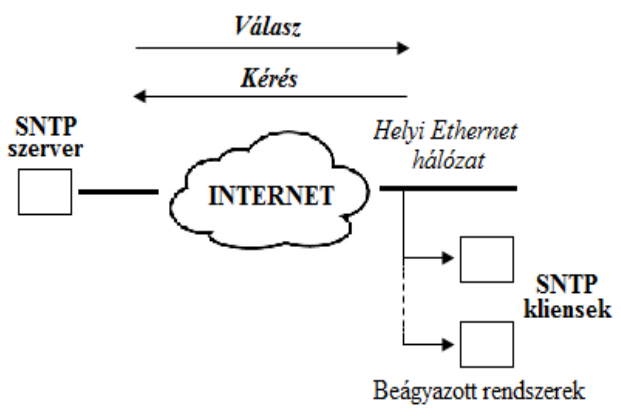

\section{3. ábra. Beágyazott SNTP szolgáltatás müködési elve}

Az SNTP kliens oldali szolgáltatás a TCP/IP referenciamodell alkalmazási rétegében helyezkedik el, és minden 10 percben kérést küld (3. ábra) egy megadott időszervernek, amely visszatéríti az aktuális időt Coordinated Universal Time (UTC) formátumban [2]. Megfelelő feldolgozás után, amennyiben eltérés mutatkozik a kapott és a mért idő között, a belső időzítő automatikusan újraszinkronizálódik. Sikertelen kapcsolódás esetén a kliensalkalmazás más időszerverek elérésével próbálkozik, egy körlistában megadott információk alapján [2]. Internethozzáférés hiányában a SCADA alkalmazás a rendszer elindulásának pillanatában kiküld egy szinkronizációs üzenetet, amely hasonló szerepet tölt be, mint az időszerver által visszatérített pontos UTC idő. 


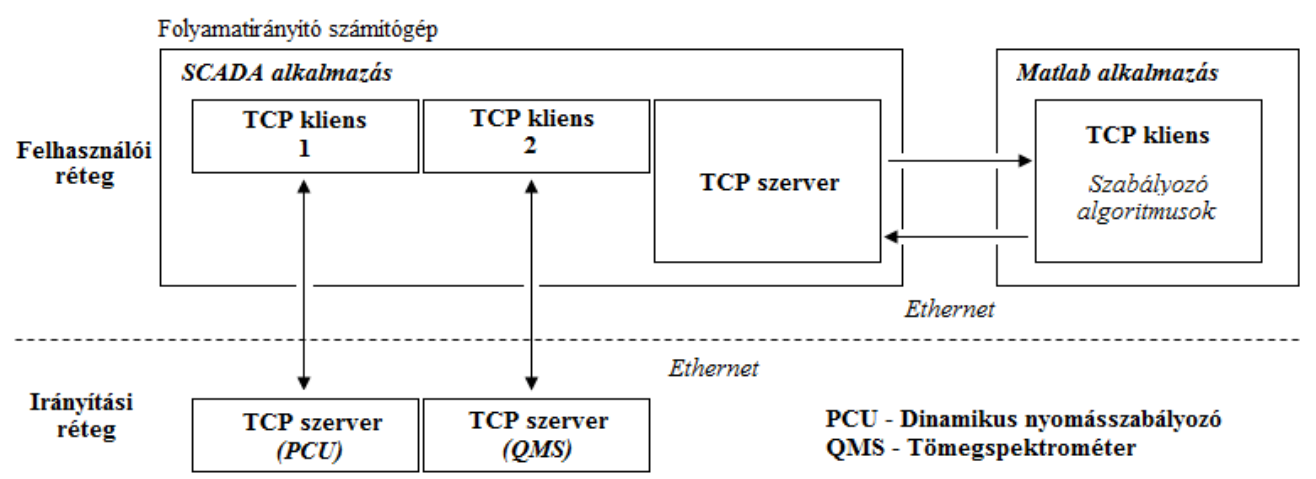

3. ábra. Kiépitett TCP kapcsolat SCADA alkalmazás és háttérben futó Matlab alkalmazás között

\subsection{A számítási kapacitás növelése - be- ágyazott Matlab alkalmazás}

Mivel a reaktív plazmaporlasztási folyamat egyes paramétereinek szabályozása komplex irányítási struktúrák használatát feltételezi, az információs rétegben kiépült egy TCP kapcsolat egy háttérben futó Matlab alkalmazás és a SCADA rendszer között, azzal a céllal, hogy stabilan müködő környezetet lehessen biztosítani a számításigényes algoritmusok lefuttatásának. Ezen eljárás kiváló tesztfelületet biztosít fejlesztési folyamatok során, hiszen Matlab környezetben online futtatni tudunk egy időben akár több szabályozási algoritmust is. Ez esetben az osztott rendszer mindhárom rétegén keresztül zárulnak a lassú szabályozási hurkok $\left(\mathrm{T}_{\mathrm{s}}>=1 \mathrm{~s}\right)$, mint például a porlasztási folyamat során használt reaktív gázok parciális nyomásainak szabályozása.

Egyedüli megkötés tehát, hogy a választott mintavételezési periódus, amelyet az adott folyamatközeli beágyazott rendszer időzít, nagyobb kell legyen, mint az osztott rendszer mérésekre alapozott maximális válaszideje, amely tartalmazza természetesen a vezérlőjel kiszámításának idejét is. $\mathrm{Az}$ utóbbi függvénye a választott szabályozási struktúra összetettségének, valamint a központi számítógép hardverkonfigurációjának. Figyelembe véve az 1. táb- lázatban összefoglalt, mérésekre alapozott három rétegen keresztül történő, pár száz miliszekundumos üzenetküldési periódusokat, valamint a lassú folyamatok másodpercnél nagyobb mintavételelezési periódusát, a javasolt beágyazott Matlab környezet alkalmas a nagyobb számításigényü szabályozási struktúrák lefuttatására.

\section{Mérési eredmények}

A mérések többnyire a kialakított többszintes rendszer adatátviteli sebességének meghatározására, valamint a különböző üzenettípusok küldési frekvenciájának ellenörzésére irányultak. Az idők mérésére a használt számítástechnikai eszközök (számítógép - SCADA alkalmazás, beágyazott mikrovezérlős alegységek - QMS, PCU) szolgáltak. Elmondhatjuk, hogy a kialakított hálózat felhasználói és irányítási rétegei között elérhető egy maximális $1 \mathrm{Mbps-os}$ adatátviteli sebesség, úgy hogy a beágyazott mikrovezérlők egy közel 20\%-os számítási kapacitástartalékkal rendelkeznek. Természetesen az 1. táblázatban bemutatott, jellegzetesebb felhasználói üzenetek küldési periódusaiból egyértelmüen látni lehet, hogy a hálózat nincs maximális kapacitással kihasználva. Ez részben a bemutatott üzenetküldési módoknak, valamint az adott mérő- és beavatkozóegységek mintavételezési periódusainak tudható be. 
1. táblázat. A jellegzetesebb felhasználói üzenetek küldési periódusai

\begin{tabular}{|c|c|c|c|}
\hline Üzenet & Réteg & $\begin{array}{c}\text { Küldési } \\
\text { típus }\end{array}$ & $\begin{array}{c}\text { Perió- } \\
\text { dus }\end{array}$ \\
\hline $\begin{array}{c}\text { Dinamikus } \\
\text { nyomás (20B) } \\
(M P T 100)\end{array}$ & 1,2 & ciklikus & $40 \mathrm{~ms}$ \\
\hline $\begin{array}{c}\text { Dinamikus } \\
\text { nyomás (30B) } \\
(M P T 100)\end{array}$ & $1,2,3$ & ciklikus & $400 \mathrm{~ms}$ \\
\hline $\begin{array}{c}\text { Védelmi } \\
\text { rendszer } \\
(\mathbf{1 6 B})(C S C)\end{array}$ & $1,2 /$ & ciklikus & $\begin{array}{c}100 \mathrm{~ms} \\
/\end{array}$ \\
\hline $\begin{array}{c}\text { Nyomás- } \\
\text { szabályozó } \\
(\mathbf{3 0 B})(P C U)\end{array}$ & $1,2 /$ & ciklikus & $\begin{array}{c}200 \mathrm{~ms} \\
/\end{array}$ \\
\hline $\begin{array}{c}\text { Tömegspekt- } \\
\text { rométer - } \\
S C A N(\mathbf{4 k B})\end{array}$ & $1,2,3,2,3$ & kérésre & $\begin{array}{c}24 \mathrm{~s} . .10 \\
\text { perc* }\end{array}$ \\
\hline $\begin{array}{c}\text { Tömegspekt- } \\
\text { rométer - } 1 \\
\text { csatorna } \\
(\mathbf{1 6 0 B})\end{array}$ & $1,2 /$ & ciklikus & $\begin{array}{c}0,3 \mathrm{~s} .3 \mathrm{~s} / \\
0,4 \mathrm{~s} . .3 \mathrm{~s} \\
*\end{array}$ \\
\hline
\end{tabular}

* Megjegyzés: A küldési periódust meghatározza a tömegspektrométer konfigurációs állománya.

A bemutatott rendszerben közel 40 különböző felhasználói üzenetet, valamint együttesen 60 mérési eredményt, származtatott értéket, rendszer- és hibaállapotot különböztetünk meg.

\section{Következtetések}

A bemutatott saját fejlesztésü és a gyakorlatban is megvalósított rendszerek a porlasztóberendezés mérő és vezérlő alegységeinek közel 40\%-át teszik ki. Következtetésképpen elmondhatjuk, hogy az időzíté- si és szinkronizálási problémákra talált megoldások, a bevezetett könnyen adaptálható csomagszerkezetek, a mérési eredmények, valamint a megvalósított beágyazott rendszerek és ezek többszintes architektúrába való szervezése lehetővé teszik a porlasztási folyamat valamennyi paraméterének mérését és szabályozását. Fontos kihangsúlyoznunk, hogy a megbízhatóan és az elöírásoknak megfelelően müködő osztott rendszer, valamint a folyamat utólagos kiértékelésére bevezetett több szinten történő adatmentés mind hozzájárul a folyamat megismételhetőségének biztosításához.

\section{Köszönetnyilvánítás}

Köszönet illeti dr. Kelemen András, dr. Bíró Domokos, dr. Papp Sándor és drd. Jakab-Farkas László urakat a bemutatott rendszer kialakítása során nyújtott nélkülözhetetlen segítségükért.

\section{Szakirodalmi hivatkozások}

[1] Fekete A. Zs., Papp S.: Modeling of dynamic and partial pressures in reactive sputtering processes. In Proceedings The $6^{\text {th }}$ edition of the Interdisciplinarity in Engineering International Conference, University of Tîrgu Mureș, Romania, 2012, pp. 249-253

[2] *** TCP/IP programcsalád leírása: Microchip TCP/IP Stack Help (verzió: 5.42 .08 - 2013), pp. 465-470

[3] Fekete A. Zs., Jakab-Farkas L.: Development of an embedded system for accessing mass spectrometry measurements through Ethernet network. Proceedings of the XXI ${ }^{\text {th }}$ International Scientific Conference of Young Engineers, Cluj-Napoca, Romania, March 17-18, pp. 161-164 